International Journal of Current Micro6iology and Applied Sciences

ISSN: 2319-7706 Volume 10 Number 11 (2021)

Journal homepage: http://www.ijcmas.com

\title{
Effect of Dietary Supplementation of Organic Minerals on Growth Performance of Broilers
}

\author{
Vinus*, N. S. Maan and B. S. Tewatia \\ Department of Animal Nutrition, LalaLajpat Rai University of Veterinary and Animal \\ Sciences, Hisar - 125004, India \\ *Corresponding author
}

Keywords

Broilers, Growth performance, Manganese, Zinc

Article Info

Received:

11 October 2021

Accepted:

05 November 2021

Available Online:

10 November 2021

\section{A B S T R A C T}

A study was conducted to assess the effects of replacing inorganic 'zinc' and 'manganese' with different levels of their organic complexes on growth performance and nutrient metabolizability of broilers. Experiment was conducted with 300 broiler chicks randomly divided into six groups, each consisting of 50 broiler chicks. All groups were further subdivided into five replications each containing 10 broiler chicks. The basal ration was formulated as per BIS (2007) specifications to meet energy and protein requirements of birds. In experimental groups, first group was kept as negative control $\left(\mathrm{T}_{1}\right)$ containing mineral mixture without 'zinc' and 'manganese' and $\mathrm{T}_{2}$ (positive control containing mineral mixture with inorganic salts of 'zinc' and 'manganese') while experimental groups $T_{3}, T_{4}, T_{5}$ and $T_{6}$ were supplemented with mineral mixture incorporated with organic 'zinc' and organic 'manganese'@50 and 100\% in substitution of their inorganic sources. The highest body weight gain (2334.4g) and improved FCR (1.76) in broilers was observed in $\mathrm{T}_{6}$ group which was significantly $(\mathrm{P}<0.05)$ better than negative and positive control groups.

\section{Introduction}

India is the fourth-largest chicken producer in the world after China, Brazil and the USA (Statista, 2017). India has exported 544,985.06 MT of poultry products to the world for the worth of Rs.687.31 crores during the year 2018-19 (APEDA). In India, the per capita consumption of chicken has gone up from 400 grams per annum, to $2.5 \mathrm{~kg}$ per annum in the last five years. The growth rate of broiler market is $8-10 \%$ per annum.

Diet plays a vital role in maintaining health and preventing diseases. In poultry diet, micro minerals deserve attention as they exert essential functions in the organism, but in modern poultry nutrition effective use of 
micro minerals are overlooked. Micro minerals, especially, 'zinc' and 'manganese' are important component of many enzymes or catalysts which play essential role in all biochemical reactions in the body. They are constituent of hundreds of protein, of vital relevance to the animal metabolism, hormone secretion pathways. Furthermore, trace mineral supplements can augment immune system function which eventually may lead to an improvement in bird's performance and be economically beneficial.

Zinc' has been found in every tissue of the bird but the element tends to accumulate in the bones rather than the liver, which is the main storage organ of the other trace elements. Most of the 'zinc' in blood is present in the erythrocytes. 'zinc' is present as a co-factor in over 300 metalloenzymes, representing all six classes of enzymes and plays an essential role in many metabolic processes, including protein synthesis (O'Dell, 1992; Salim et al., 2008). 'Zinc' is also a component of lactic dehydrogenase and, therefore, is important for the conversions of pyruvic acid and lactic acid. Also, 'zinc' is a component part of some peptidases and therefore is important for digestion of proteins in the gastrointestinal tract. So deficiency of 'zinc' would exert a negative influence on protein and carbohydrate metabolism and leads to reduced feed intake, decreased growth, poor FCR, abnormalities in immunological, reproductive processes, skeletal and skin tissues (Underwood and Suttle, 1999).In chicks, 'zinc' deficiency symptoms include, slow growth, shortened and thickened long bones and poor feathering, with keratosis resulting when the deficiency is severe.

Manganese' ('Mn') is also a necessary trace mineral in the activation of metalloenzymes that contribute to the metabolism of carbohydrates, lipids and amino acids (Suttle, 2010). 'Manganese' is required for oxidative phosphorylation in mitochondria, fatty acid synthesis and acetate incorporation into cholesterol, mucoploysaccharide synthesis and bone matrix cell maturation in chicks. It is also an important component of the ' $\mathrm{Mn}$ ' superoxide dismutase ('Mn'-SOD) that protects cells from oxidative stress (Li et al., 2011). 'Manganese' also participate in various structural and physiological functions, which include oxidant defense system, also plays a significant role in the chicken's body in the formation of chondroitin sulfate which is required for the formation of skeletal and cartilage tissue. Deficiency of 'manganese' in poultry will result in perosis, bone shortening, bowing.

In commercial poultry diets, the majority of these trace minerals are supplemented as inorganic forms (sulphate or oxide salts) which suffer from high rates of loss due to dietary antagonism. Use of organically complexed trace minerals can help to prevent these losses, due to increased stability in the upper gastrointestinal tract. Also competition for the same or similar carriers is a major interference when metals are transferred from the lumen into the enterocyte (Hill \& Matrone, 1970). Use of organically complexed or chelated minerals in premixes has been suggested as a solution to this problem.

\section{Materials and Methods}

Three hundred, day old broiler chicks were randomly divided into six treatment groups with 5 replicates of 10 birds in each replication following completely randomized design (CRD).

Feed ingredients used in the diet formulations were analyzed for the proximate nutrients (AOAC, 2013). The ingredient and chemical composition of diet given during pre-starter, starter and finisher phases is presented in Table 1.Basal ration formulated as per BIS 
(2007) to fulfill the metabolizable energy (ME), crude protein and limiting amino acids (methionine and lysine) requirement of birds. Level of crude protein in pre-starter and starter ration was 22 percent and in finisher phase 20 percent. The respective ME content was 3001.7 and $3154.2 \quad \mathrm{KCal} / \mathrm{kg}$. Chemical composition of feed ingredients used to formulate the basal ration is given in Table 2 .

Moisture, dry matter, crude protein, crude fibre, ash, NFE, ME, 'zinc' and 'manganese' are analysed data.

For the experimental diets, mineral mixture was prepared using inorganic forms of all components except 'Zn' and 'Mn'. Organically complexed ' $\mathrm{Zn}$ ' and 'Mn' were separately added in mineral mixture at proportion of their inorganic form in positive control group.

In dietary treatments, first group was kept as negative control $\left(\mathrm{T}_{1}\right)$ containing mineral mixture without zinc and manganese and $\mathrm{T}_{2}$ (positive control containing mineral mixture with inorganic salts of zinc and manganese) while experimental groups $\mathrm{T}_{3}, \mathrm{~T}_{4}, \mathrm{~T}_{5}$ and $\mathrm{T}_{6}$ were supplemented with organic zinc and organic manganese @ 50 and $100 \%$ in substitution of inorganic sources. Birds were reared in deep litter system at poultry farm and were offered feed and water ad libitum through linear feeder and waterer. Proper ventilation was also provided.

A metabolism trial was conducted during $6^{\text {th }}$ week of growth period and one bird from each replicate was randomly selected and transferred to metabolic cages. A preliminary period of two days was given for adaptation to the birds to new system of housing and management, followed by a collection period of three days. Weighed polythene sheets of appropriate size were spread over the dropping trays for the collection of excreta. After completion of preliminary feeding, the birds were offered weighed amount of experimental diets at one time in the morning and ad libitum drinking water was provided. On the next day, the polythene sheets with excreta were removed and weighed after removing feeds and feathers, if any. Representative samples from thoroughly mixed excreta were drawn daily for total dry matter voided. New polythene sheets were weighed and spread on the tray to record observations for the next day. Thus, the feed residue and excreta voided was weighed and properly recorded for final calculations of the total daily feed consumption and excreta voided.

During the trial, the birds were weighed individually at fortnightly interval and the body weights were recorded to calculate body weight gain in 0-4 weeks, 4-6 weeks and 0-6 weeks. Fortnightly feed intake and residue left per replicate was measured throughout the experiment to calculate the feed consumption per bird. Feed conversion ratio (FCR) for each replicate was calculated as follows:

FCR $=\frac{\text { Total feed consumed }(g)}{\text { Total body weight gain }(\mathrm{g})}$

\section{Statistical Analysis}

The resultant data were statistically analysed according to the procedure laid down by Snedecor and Chochran, (1994). Analysis of variance was used to study the differences among treatment means and they were compared by using Duncan's Multiple Range Test (DMRT) as modified by Kramer (1956).

\section{Results and Discussion}

\section{Body Weight Gain}

Performance analysis showed that BW differ significantly in organic minerals treated groups from the negative control group $\left(T_{1}\right)$ 
during 0-4 weeks of the experimental period. However, all supplemented groups including inorganic minerals supplemented group manifested higher mean BW gain as compared to the negative control group. During 4-6 weeks of the experiment $\mathrm{T}_{6}$ group $(1207.80 \mathrm{~g}$ ) resulted into significantly $(\mathrm{P}<0.05)$ higher $\mathrm{BW}$ gain followed by $\mathrm{T}_{4}(1118.6 \mathrm{~g})$ and $\mathrm{T}_{4}$ (1080.2g) groups. Organic minerals supplemented broiler birds $\left(\mathrm{T}_{6}, \mathrm{~T}_{4}, \mathrm{~T}_{5}\right.$ and $\mathrm{T}_{3}$ respectively) had significantly $(\mathrm{P}<0.05)$ better effect on mean $\mathrm{BW}$ gain as compared to the inorganic $\left(\mathrm{T}_{2}\right)$ and negative control $\left(\mathrm{T}_{1}\right)$ during $0-6$ weeks. At the end of 42 days of age, highest BW was found in broilers fed with $100 \%$ organic minerals $(2334.4 \mathrm{~g})$ followed by $\mathrm{T}_{4}(2194.8 \mathrm{~g})$ and $\mathrm{T}_{5}(2173 \mathrm{~g})$ groups and exhibited significant variance from negative control (1966.8g) and inorganic minerals supplemented group (2037.20g).

The results of higher body weight gain in organic minerals supplemented group was due to important role of ' $\mathrm{Zn}$ ' and ' $\mathrm{Mn}$ ' in several biochemical reactions, in maintaining the structure of metalloproteins such as insulin, growth hormone and the live performance improvements detected in the present study may be explained by the fact that the supplemented minerals in organic form met the requirements of enzymes that have a main role in the synthesis of DNA, RNA and body protein (Karamouz et al., 2010).

The findings of present study are in accordance with those of El-Husseiny et al., (2012) who revealed significant $(\mathrm{P}<0.05)$ effect of $50 \%$ ' $\mathrm{Zn}$ ' $+50 \%$ 'Mn' $+50 \% \mathrm{Cu}$, added as organic minerals, improved growth performance of broilers. The results obtained in the experiment corroborate well with the findings of Rao et al., 2016; Saleh et al., 2018 who concluded that growth performance in terms of increased body weight gain was significantly affected with supplementation of broiler's diet with organic ' $\mathrm{Zn}$ '. Furthermore, 'Zn' positively affects feed utilization through participating in the metabolism of carbohydrates, lipids and proteins (Macdonald 2000) which finally translated into improvements in growth performance.

\section{Feed Intake}

Table 4 represents average feed intake (g/bird) of experimental broiler birds during different growth periods under different dietary treatments. The initial 0-4weeks and 46weeks, average feed intake of the broiler birds belonging to different treatments was similar.

Mean values of feed intake during overall growth period (0-6weeks) were significantly $(\mathrm{P}<0.05)$ higher in organic minerals supplemented group $\left(\mathrm{T}_{6}\right)$ as compared to negative control group and highest feed intake was recorded in $\mathrm{T}_{6}$ group. During overall growth period (0-6weeks) feed intake ranged between $3804.62 \mathrm{~g}\left(\mathrm{~T}_{6}\right)$ and $3486.02 \mathrm{~g}\left(\mathrm{~T}_{1}\right)$ and lowest feed intake was observed in negative control. There was significant $(\mathrm{P}<0.05)$ difference amid the group fed with $100 \%$ organic minerals as compared to negative control with regard to feed intake.

Higher feed intake obtained in organic minerals supplemented groups might be due to better growth and increased body weight gain. Additionally, through participating in the metabolism of carbohydrates, lipids and proteins (Macdonald 2000) organic ' $\mathrm{Zn}$ ' and 'Mn' increases the feed utilization. Deficiency of these minerals strongly affect feed intake, which led to depressed growth of broilers (Bao et al., 2007). 
Table.1 Ingredients and Chemical Composition (\%DM Basis) of Experimental Diets in Different Growth Phases of Broiler Chicks

\begin{tabular}{|c|c|c|c|}
\hline Ingredients (Kg/100kg) & Pre-starter & Starter & Finisher \\
\hline Maize & 58 & 58 & 60 \\
\hline Soyabean Meal & 30 & 30 & 25 \\
\hline Fish Meal & 7 & 7 & 7 \\
\hline Vegetable Oil & 3 & 3 & 6 \\
\hline Mineral Mixture & 2 & 2 & 2 \\
\hline \multicolumn{4}{|c|}{ Feed additives $(\mathrm{g} / 100 \mathrm{~kg}$ feed $)$} \\
\hline Spectromix & 10 & 10 & 10 \\
\hline Spectromix BE & 20 & 20 & 20 \\
\hline Chlortetracycline & 33.5 & 33.5 & 33.5 \\
\hline Veldot & 50 & 50 & 50 \\
\hline Choline chloride & 50 & 50 & 50 \\
\hline Lysine & 50 & 50 & 50 \\
\hline DL-methionine & 150 & 150 & 150 \\
\hline \multicolumn{4}{|c|}{ Chemical Composition (\%DMB) } \\
\hline Moisture & 11.54 & 11.54 & 11.48 \\
\hline Dry Matter & 88.46 & 88.46 & 88.52 \\
\hline Crude Protein & 22.01 & 22.01 & 20.10 \\
\hline Ether Extract & 3.32 & 3.32 & 3.61 \\
\hline Crude Fibre & 4.89 & 4.89 & 4.85 \\
\hline Ash & 9.11 & 9.11 & 9.22 \\
\hline Nitrogen Free Extract & 49.13 & 49.13 & 50.74 \\
\hline Metabolizable Energy $(\mathrm{Kcal} / \mathrm{Kg})$ & 3001.7 & 3001.7 & 3154.2 \\
\hline 'Zinc' $(\mathrm{mg} / \mathrm{Kg})$ & 23.63 & 23.63 & 22.67 \\
\hline 'Manganese'(mg/Kg) & 6.24 & 6.24 & 5.53 \\
\hline
\end{tabular}

Table.2 Chemical Composition of Feed Ingredients

\begin{tabular}{|c|c|c|c|c|c|c|c|c|}
\hline Ingredient & $\begin{array}{c}\text { CP } \\
(\boldsymbol{\%})\end{array}$ & $\begin{array}{c}\text { EE } \\
(\boldsymbol{\%})\end{array}$ & $\begin{array}{c}\text { CF } \\
(\boldsymbol{\%})\end{array}$ & $\begin{array}{c}\text { TA } \\
(\boldsymbol{\%})\end{array}$ & $\begin{array}{c}\text { Lysine* } \\
(\boldsymbol{\%})\end{array}$ & $\begin{array}{c}\text { Methionine* } \\
(\boldsymbol{\%})\end{array}$ & $\begin{array}{c}\mathbf{M E}^{*} \\
(\mathbf{k c a l} / \mathbf{k g})\end{array}$ & $\begin{array}{c}\text { Cost } \\
(\mathbf{R s .})\end{array}$ \\
\hline Maize & 9.10 & 3.44 & 2.44 & 2.25 & 0.18 & 0.15 & 3300 & 1545 \\
\hline $\begin{array}{c}\text { Soyabean } \\
\text { meal }\end{array}$ & 45.2 & 3.16 & 3.93 & 8.47 & 2.57 & 0.76 & 2230 & 2722 \\
\hline Fish meal & 47.4 & 1.76 & 5.15 & 26.6 & 1.42 & 1.42 & 2210 & 3847 \\
\hline
\end{tabular}

*calculated values Singh and Panda (1998) 
Table.3 Body weight gain $(\mathrm{g})$ in broiler chicks during different growth periods under different dietary treatments

\begin{tabular}{|c|c|c|c|}
\hline \multirow{2}{*}{ Treatments } & \multicolumn{3}{|c|}{ Mean Body Weight Gain(g) } \\
\cline { 2 - 4 } & $\mathbf{0 - 4 w e e k s}$ & 4-6 weeks & 0-6weeks \\
\hline $\mathbf{T}_{\mathbf{1}}$ & $1019.20^{\mathrm{c}} \pm 23.20$ & $947.60^{\mathrm{a}} \pm 17.64$ & $1966.80^{\mathrm{e}} \pm 12.36$ \\
\hline $\mathbf{T}_{\mathbf{2}}$ & $1080.60^{\mathrm{b}} \pm 10.93$ & $956.60^{\mathrm{a}} \pm 43.35$ & $2037.20^{\mathrm{de}} \pm 52.30$ \\
\hline $\mathbf{T}_{\mathbf{3}}$ & $1089.80^{\mathrm{a}} \pm 12.95$ & $1015.80^{\mathrm{a}} \pm 23.48$ & $2105.60^{\mathrm{cd}} \pm 26.71$ \\
\hline $\mathbf{T}_{\mathbf{4}}$ & $1076.20^{\mathrm{b}} \pm 11.44$ & $1118.60^{\mathrm{b}} \pm 27.02$ & $2194.80^{\mathrm{b}} \pm 26.25$ \\
\hline $\mathbf{T}_{\mathbf{5}}$ & $1092.80^{\mathrm{a}} \pm 6.65$ & $1080.20^{\mathrm{b}} \pm 23.48$ & $2173.00^{\mathrm{bc}} \pm 19.51$ \\
\hline $\mathbf{T}_{\mathbf{6}}$ & $1126.60^{\mathrm{a}} \pm 10.73$ & $1207.80^{\mathrm{a}} \pm 21.06$ & $2334.40^{\mathrm{a}} \pm 15.35$ \\
\hline
\end{tabular}

Means bearing different superscripts in a column differ significantly $(\mathrm{P}<0.05)$

Table.4 Feed intake (g) during different growth periods in broiler chicks under different dietary treatments

\begin{tabular}{|c|c|c|c|}
\hline \multirow{2}{*}{ Treatments } & \multicolumn{3}{|c|}{ Feed Intake $(\mathbf{g})$} \\
\cline { 2 - 4 } & $\mathbf{0 - 4}$ weeks & 4-6 weeks & $\mathbf{0 - 6}$ weeks \\
\hline $\mathbf{T}_{\mathbf{1}}$ & $1598.26 \pm 76.91$ & $1887.76^{\mathrm{b}} \pm 82.73$ & $3486.02^{\mathrm{c}} \pm 31.48$ \\
\hline $\mathbf{T}_{\mathbf{2}}$ & $1665.51 \pm 46.78$ & $1880.45^{\mathrm{b}} \pm 107.41$ & $3536.96^{\mathrm{b}} \pm 44.93$ \\
\hline $\mathbf{T}_{\mathbf{3}}$ & $1707.45 \pm 63.85$ & $1949.80^{\mathrm{a}} \pm 59.26$ & $3657.25^{\mathrm{a}} \pm 57.22$ \\
\hline $\mathbf{T}_{\mathbf{4}}$ & $1696.05 \pm 32.10$ & $2100.11^{\mathrm{a}} \pm 65.44$ & $3796.05^{\mathrm{a}} \pm 67.52$ \\
\hline $\mathbf{T}_{\mathbf{5}}$ & $1720.53 \pm 37.79$ & $1982.80^{\mathrm{a}} \pm 97.32$ & $3703.53^{\mathrm{a}} \pm 61.41$ \\
\hline $\mathbf{T}_{\mathbf{6}}$ & $1657.96 \pm 24.59$ & $2146.66^{\mathrm{a}} \pm 54.23$ & $3804.62^{\mathrm{a}} \pm 59.65$ \\
\hline
\end{tabular}

Means bearing different superscripts in a column differ significantly $(\mathrm{P}<0.05)$

Table.5 Feed conversion ratio during different growth periods in broiler chicks under different dietary treatments

\begin{tabular}{|c|c|c|c|}
\hline \multirow{2}{*}{ Treatments } & \multicolumn{3}{|c|}{ Feed conversion ratio } \\
\cline { 2 - 4 } & $\mathbf{0 - 4}$ weeks & $\mathbf{4 - 6}$ weeks & $\mathbf{0 - 6}$ weeks \\
\hline $\mathbf{T}_{\mathbf{1}}$ & $1.57 \pm 0.04$ & $1.99^{\mathrm{a}} \pm 0.06$ & $1.99^{\mathrm{a}} \pm 0.01$ \\
\hline $\mathbf{T}_{\mathbf{2}}$ & $1.53 \pm 0.04$ & $1.98^{\mathrm{a}} \pm 0.07$ & $1.97^{\mathrm{a}} \pm 0.01$ \\
\hline $\mathbf{T}_{\mathbf{3}}$ & $1.57 \pm 0.05$ & $1.93^{\mathrm{a}} \pm 0.09$ & $1.88^{\mathrm{b}} \pm 0.03$ \\
\hline $\mathbf{T}_{\mathbf{4}}$ & $1.58 \pm 0.03$ & $1.87^{\mathrm{a}} \pm 0.02$ & $1.87^{\mathrm{b}} \pm 0.01$ \\
\hline $\mathbf{T}_{\mathbf{5}}$ & $1.57 \pm 0.03$ & $1.83^{\mathrm{a}} \pm 0.06$ & $1.84^{\mathrm{b}} \pm 0.02$ \\
\hline $\mathbf{T}_{\mathbf{6}}$ & $1.47 \pm 0.02$ & $1.78^{\mathrm{b}} \pm 0.02$ & $1.76^{\mathrm{c}} \pm 0.02$ \\
\hline
\end{tabular}

Means bearing different superscripts in a column differ significantly $(\mathrm{P}<0.05)$

These results coincide with the significantly higher feed intake recorded on replacement of inorganic 'zinc' with organic form (Rao et al., 2016: Mishra et al., 2013) as the first sign of ' $\mathrm{Zn}$ ' deficiency in broiler chickens is decreased feed intake followed by poor growth. Contrary to these findings, Rossi et al., (2007) reported that the feed consumption was not influenced by addition of dietary organic ' $\mathrm{Zn}$ ' in broilers.

\section{Feed Conversion Ratio (FCR)}

In this study, FCR was better in organic minerals supplemented groups. Since the values were close to each other in different 
dietary treatments, there was no statistical difference during initial 0-4 weeks of experimental period. The higher values for FCR were observed in $\mathrm{T}_{2}$ (positive control) and those of the lowest values were for organic minerals fed groups $\mathrm{T}_{6} \quad(1.78)$ followed by $\mathrm{T}_{5}$ (1.83) group and significant $(\mathrm{P}<0.05)$ difference was there at $22-42$ days of age.

The cumulative FCR for overall growth period $(0-42 \mathrm{~d})$, was found better in $100 \%$ organic minerals supplemented group $\mathrm{T}_{6}$ (1.76), followed by $\mathrm{T}_{5}$ (1.84) and $\mathrm{T}_{4}(1.87)$ and were varied significantly as compared to the negative control and inorganic minerals supplemented group. These results are in accordance with the findings of Bao et al., (2007) that the organic supplements had positive effects on FCR. Improved FCR might be due to increased activity of digestive enzymes on addition of organic 'zinc' and 'manganese'. These minerals have a protective role on pancreatic tissue against oxidative stress, these might help pancreas to function properly including secretion of digestive enzymes thus improving the digestibility. Supplemental organic 'zinc' alone or in combination with other elements, 'Mn', $\mathrm{Cu}$ and $\mathrm{Fe}$, significantly improved body weight gain and FCR (Bao et al., 2010). Differing from this result, Rossi et al., 2007; Mishra et al., 2013 who reported that feed conversion ratio was not influenced by addition of organic 'Zn'.

\section{References}

AOAC (2013). Official Methods of Analysis. $16^{\text {th }}$ ed. Association of Official Analystical Chemists, Arlington, Verginia, USA. BIS, (1992), Nutrient Requirements for Poultry IS:9883 Bureau of Indian Standard, New Delhi, India.

APEDA. www.apeda.gov.in.
BIS, (2007). Nutrient Requirements for Poultry IS:9883 Bureau of Indian Standards, New Delhi, India.

El-Husseiny, O. M., Hashish, S.M., Ali, R. A., Arafa, S.A., El- Samee, L. D. A. and Olemy, A. A. (2012). Effects of feeding organic 'zinc', 'manganese' and 'copper' on broiler growth, carcass characteristics, bone quality and mineral content in bone, liver and excreta. Int J Poult Sci., 11 (6): 368377.

Hill, C. H. and Matrone, G. (1970). Chemical parameters in the study of in vivo and in vitro interactions of transition elements. Federation Proceedings; 29:1474-81.

Karamouz, H., Shahryar, H. A., Gorbani, A., Maheri-Sis, N. and Ghaleh-Kandi, J. G. (2010). Effect of 'zinc' oxide supplementation on some serum biochemical values in male broilers. Global Vet.,4(2):108-111.

Kramer, C. Y. (1956). Extension of multiple range test to group means with unequal number of replicates. Biomet. 12: 307310.

Li, S., Lu, L., Hao, S., Wang, Y., Zhang, L., Liu, S., Liu, B., Li, K. and Luo, X. (2011). Dietary 'manganese' modulates expression of the 'manganese' containing superoxide dismutase gene in chickens. J Nutr., 141: 189-194.

Li, S., Lu, L., Hao, S., Wang, Y., Zhang, L., Liu, S., Liu, B., Li, K. and Luo, X. (2011). Dietary 'manganese' modulates expression of the 'manganese' containing superoxide dismutase gene in chickens. $J$ Nutr., 141: 189-194.

Mcdonald, R. S. (2000). The role of 'zinc' in growth and cell prolifereation. J Nutri., 130:1500-1508.

Mishra, S. K., Swain, R. K., Behura, N. C., Das, A., Mishra, A., Sahoo, G. and 
Dash, A. K. (2013). Effect of supplementation of organic minerals on the performance of broilers. Indian J Anim Sci., 83 (12): 1335-1339.

O'Dell, B. L. (1992) 'zinc' plays both structural and catalytic roles in metalloproteins. Nutr Reviews., 50: 539-452.

Rao, R. S., Prakash, V. B., Raju, M. V. L., Panda, N. A. K., Kumari, R. K. and Reddy, E. P. K. (2013). Effect of supplementing organic forms of 'zinc', selenium and chromium on performance, anti-oxidant and immune responses in broiler chicken reared in tropical summer. J Biol Trace Elem Res., 172:511-520.

Rao, R. S., Prakash, V. B., Raju, M. V. L., Panda, N. A. K., Kumari, R. K. and Reddy, E. P. K. (2013). Effect of supplementing organic forms of 'zinc', selenium and chromium on performance, anti-oxidant and immune responses in broiler chicken reared in tropical summer. J Biol Trace Elem Res., 172:511-520.

Rossi, P., Rutz, F., Anciuti, M. A. and Rech, J. L. (2007). Influence of graded levels of organic 'zinc' on growth performance and carcass traits of broilers. $J$
ApplPoult Res., 16(2):DOI: 10.1093/japr/16.2.219.

Saleh, A. A., Ragab, M. M., Ahmed, E. A. M., Abudabos, A. M. and Ebeid, T A. (2018). Effect of dietary 'zinc'methionine supplementation on growth performance, nutrient utilization, antioxidative properties and immune response in broiler chickens under high ambient temperature. J ApplAnimRes., 46:(1), 820-827.

Salim, H., Jo, C. and Lee, B. (2008). 'Zinc' in broiler feeding and nutrition. Avian Biol Res., 1:5-18.

Singh, K. S. and Panda, B. (1998). Poultry Nutrition. ( $1^{\text {st }}$ Ed). Kalyani Publishers, New Delhi, India. 282-293.

Snedecor, G. W. and Cochran, W. G. (1994). Statistical Methods, $6^{\text {th }}$ edn. The lowa State University Press, Ames, lowa.

Statista (2017). Meat, dairy and poultry product export in India by value 20102017. https://www.statista.com.

Suttle, N. F. (2010). The mineral nutrition of livestock, $4^{\text {th }}$ edition, CABI Publishing, Oxfordshire, UK.

Underwood, E. J. and Suttle, N. F. (1999). The mineral nutrition of livestock. $3^{\text {rd }}$ ed. CABI Publishing, New York.

\section{How to cite this article:}

Vinus, N. S. Maan and Tewatia, B. S. 2021. Effect of Dietary Supplementation of Organic Minerals on Growth Performance of Broilers. Int.J.Curr.Microbiol.App.Sci. 10(11): 235-242. doi: https://doi.org/10.20546/ijcmas.2021.1011.027 